\title{
Evaluation of Field Work Practice Programs with Using Logic Model
}

\author{
Ilham Juliwardi ${ }^{*}$, Sukardi², Krismadinata ${ }^{3}$
}

1,2,3 Fakultas Teknik, Universitas Negeri Padang

A R T I C L E I N F O

Article history:

Received 15 May 2019

Received in revised

form

29 June 2019

Accepted 18 July 2019

Available online 30

August 2019

Keywords:

Input, Process, Output

And Outcome

\section{A B S T R A C T}

This study aims to evaluate the Implementation of Field Work Practices of SMK Negeri 1 Padang. Evaluation of Field Work Practices is seen from the aspects of Input, Process, Output, Outcome faced in the implementation of street vendors. The research method used is a combination of Concurrent Embedded design methods, combining quantitative and qualitative research methods sequentially, where in the first stage the study uses quantitative methods and in the second stage qualitative methods. The results showed that the Implementation of Field Work Practices at SMK Negeri 1 Padang Electrical Engineering expertise program as a whole included. Input evaluation according to reality obtained an average standard score of $74.27 \%$ with the Fair category, and Input evaluation according to expectations obtained an average standard score of $89.58 \%$ with the Very Good category. Process Indicators according to reality obtained a percentage level of $74.14 \%$ with the category Fair. As for the Process indicator as expected, a percentage level of $88.56 \%$ was obtained with the Good category. Output indicators according to reality obtained a percentage level of $72.65 \%$ with the category Fair. As for the Output indicator as expected, a percentage level of $89.13 \%$ was obtained. with the category of Very Good. Outcome indicators according to reality obtained a percentage level of $72.36 \%$ with the category Fair. As for the Outcome indicator as expected, a percentage level of $88.41 \%$ was obtained with the Good category. Based on the findings of this study it was concluded that the Field Work Practices program for students in the SMK Negeri 1 Padang were still in the Fair category, which needed to be improved for each aspect. 


\section{Introduction}

Vocational education is education that is expected so that graduate students can immediately get work in accordance with their educational background and expertise they have learned while pursuing education at a vocational education program. Meanwhile the aim of vocational education has the aim to (1) provide skills that are sold in the community, so that it can support economic life, (2) help students obtain and maintain the jobs they want, (3) encourage economic productivity economically regionally and nationally, (4) encourage the growth of trained personnel to sustain economic and industrial growth, and (5) encourage the improvement of the quality of society. National education according to Law No. 20 of 2003 the National Education System is education that prepares students to be able to work in certain fields, then Government Regulation No. 19 of 2005 concerning National Education Standards, explains that Vocational Secondary School (SMK) is an education at the secondary level that enhances the development of students' abilities for certain types of work.

One of the problems related to the quality of vocational graduates is not yet ready for vocational graduates to enter DU / DI. Before the vocational graduates are ready to do the work in the work world, it has a domino effect on the industry of labor users, because the industry must organize education in the industry to prepare the workforce. Actually the industry and the school have their respective limitations in forming and getting ready-to-use labor. Schools have limitations in financing and providing a learning environment, while the industry has limitations in educational resources to shape the workforce needed. Therefore, to get vocational graduates who are ready to use, then both parties should make an effort, or be involved in compiling a training program. Evaluation is a process carried out by someone to see the success of a program. The success of the program itself can be seen from the impact or the results achieved by the program. Therefore, in success there are two concepts contained therein, namely effectiveness and efficiency. Logic Model, is a tool for planning the program to be implemented. Besides that, the logic model can also be used to evaluate programs or activities that have been completed or are currently running and programs that are still in the planning stage. There are several researchers who use this evaluation model, including:

Of the several studies conducted by researchers using the Logic Model, no one has evaluated the Field Work Program (Field Work Practice) using the Logic Model, in the research conducted by the researchers, they only conducted research including the Social Workers Training Program (Social Workers) ), Dual System Education Program (PSG), Vocational Life Skills Based Entrepreneurship Learning Learning Program. Research on programs that have been carried out by researchers, they only conduct qualitative research, while on PKL program evaluation research which will be examined using the Logic Model with the Mix Methods research method, which is a mixed method between quantitative research and qualitative research, in this study also researchers used 2 kinds of questionnaires, namely online questionnaires and manual questionnaires (print out), the use of these two types of questionnaires was caused because the students were not all carrying out street vendors in the surroundings of the Province of Sumatra, West Sumatra. implement street vendors outside the Province of West Sumatra, such as Riau Province, Batam Province, Bengkulu Province and others. So for students who implement street vendors outside West Sumatra Province will be given an online questionnaire. SMK Negeri 1 Padang is one of the vocational high schools in the technology and engineering groups that carry out street vendors. PKL program is integrated in the curriculum of SMK Negeri 1 Padang, in order to produce quality Lulu-san and in accordance with DU / DI needs. State Vocational High School 1 Padang implements the apprenticeship program every school year. So that these activities do not interfere with regular learning activities, the PKL activities are carried out at the end of the even semester or at the beginning of the odd semester. Participants who took part in the PKL program at SMK Negeri 1 Padang were all students sitting in class XI for each expertise program.

By evaluating the program, it will be known which program components have not been realized, so that it can be improved and implemented in the next program. whereas for students the evaluation of the implementation of the street vendors program will function as a feedback team in improving their competency and learning outcomes.

Researchers consider it important to carry out evaluations in the PKL SMK Negeri 1 Padang TP program. 2018/2019, because the PKL SMK Negeri 1 Padang Program has never been evaluated. Evaluation of PKL Program in SMK Negeri 1 Padang is needed to look deeply into each component of the PKL Program with the Logic Model Evaluation Model (Input, Testing, Output, Outcome). 


\section{Methods}

This research is a combination of research, namely a combination of qualitative methods with quantitative methods (Mixed Methods Research) as stated by Creswell (2014: 230) that the mixed research method is a qualitative approach in a study. Evaluation is carried out with a Logic Model that includes Component Resources (Input), Activity (Process), (Output), (Outcome).

The reason for research using mixed methods research (Mixed Method Research) is to eliminate the weaknesses of quantitative and qualitative methods.

The design of this study uses Con-crurrent Embedded. The research design combines the Concrurrent Embedded model, which is a research model that combines quantitative and qualitative research methods simultaneously or together, but the weights are different. This study collected quantitative data as primary data and qualitative data as secondary data carried out at the same time, or at different times but not too long. Primary and secondary data are analyzed separately according to the type of data (quantitative and qualitative). then the two types of data are interpreted in a descriptive form after which they are combined into research findings data. The findings obtained subsequently describe clearly the evaluation of the PKL SMK Negeri 1 Padang program evaluation

The research data was taken by using a questionnaire or questionnaire, research questionnaire items were made and arranged based on the instrument grid. The research questionnaire was answered by two types of respondents, namely students and PKL supervisors. This division is made so that questions about students are not answered by the students themselves, as well as for the supervising teacher not answering questions about the supervising teacher. Qualitative instructors in the form of interview guidelines that contain a sequence of questions arranged based on indicators and sub-indicators as a guide to get information from research informants.

\section{Result and Discussion}

\section{A. Quantitative Data Analysis}

a) Input Aspects

The input aspects consist of six indicators, namely the objectives of the street vendors program, the readiness of students, the readiness of the supervising teacher, the readiness of the DUDI instructor, the readiness of facilities and infrastructure and the relevance of the program to the needs of students. Through comparison of the results of respondents' achievement levels according to reality and according to expectations, there is a gap between reality and expectations, where in fact, the percentage obtained for indicators of the relevance of PKL program is $73.18 \%$, whereas the expectations obtained by a percentage of $88.54 \%$. So that improvements are needed in the preparation of teaching materials and learning objectives, so that it can provide relevance between the material / practice carried out in schools with those found in the field.

Based on the analysis of the level of achievement of respondents the overall Input indicators according to reality obtained a percentage level of $74.27 \%$ with the category Fair. While for the Input indicator as expected, a percentage level of $89.58 \%$ was obtained with a very good category.

\section{b) Process Aspects}

Process aspects are divided into three indicators, namely the implementation of the apprenticeship program, monitoring the implementation of street vendors and the obstacles to the implementation of street vendors.

Through comparison of the results of the respondent's achievement level according to reality and according to expectations, there is a gap between reality and expectations, where in fact the percentage obtained for indicators of obstacles in the implementation of street vendors is $70.16 \%$ while in the expectation a percentage of $86.54 \%$ is obtained. So that improvements are needed in the form of adjustments to the PKL departure schedule that has been set and granting permission from the agency to PKL participants in using the tools there.

Based on the analysis of the level of achievement of respondents overall Process indicators in accordance with the reality obtained a percentage level of $74.14 \%$ with the category Fair. As for the Process indicator as expected, a percentage level of $88.56 \%$ was obtained with the Good category.

\section{c) Output Aspects}

The output aspect consists of one in-dictator, namely the assessment of the learning of PKL participants. Through the comparison of the results of the respondent's achievement level according to reality and according to expectations the gap is obtained between reality and expectations, where in fact a 
percentage is obtained for the assessment indicators of PKL participant learning at $72.65 \%$ while the expectations obtained by a percentage of $89.13 \%$. So that improvements are needed in the form of increasing the relevance of the material taught at school to those obtained in industry, giving input / direction from instructors in industry so that students gain new knowledge.

\section{d) Outcome Aspects}

Outcome aspect which consists of one indicator, namely Improvement of students' competence and changes in attitudes of students after implementing street vendors Through comparison of the results of respondents 'achievement levels according to reality and according to expectations, there is a gap between the reality and expectations, where in reality the percentage obtained for the indicator of students' attitude change after implementing street vendors is $75.25 \%$ while in their expectations a percentage is obtained of $90.43 \%$ so that improvements are needed, so that changes in student attitudes after implementing street vendors can change for the better.

Based on the analysis of the level of achievement of respondents the overall Outcome indicator according to the reality obtained a percentage level of $72.36 \%$ with the category of Fair. Whereas for outcome indicators according to the results obtained a percentage level of $88.41 \%$ with the Good category

Table 1. Tingkat Capaian Responden (TCR)

\begin{tabular}{clccc}
\hline No & & Aspek & TCR & Kategori \\
\hline 1 & Input & & 74,27 & Cukup \\
2 & Process & & 74,14 & Cukup \\
3 & Output & 72,65 & Cukup \\
4 & Outcome & 72,36 & Cukup \\
\hline
\end{tabular}

\section{B. Qualitative Data Analysis}

a) Input Aspects

Related to the Input aspect, qualitative data were obtained from interviews with the head of the PKL program, the head of the expertise program, the supervisor of the PKL program, supervisors, and PKL participant students. Based on interviews that have been conducted, it can be concluded that: a) The objectives of the PKL program have been achieved well, b) the teacher has been briefed before the PKL begins, c) the facilities and infrastructure are sufficient enough to support PKL, d) students are trying prepare themselves before the PKL is implemented, e) for the relevance of the material, there are some materials that are less relevant to the needs of the industry, f) the lack of clear guidance before the PKL given by the school.

\section{b) Process Aspects}

Related to the aspects of the process, qualitative data were obtained from interviews with the head of the street vendors program, the head of the expertise program, the supervisor of the street vendors program, supervisors and students participating in street vendors

Based on interviews that have been carried out, it can be concluded that: a) the overall street vendors program has been quite good, but not everything is going well, b) for street vendors obstacles viewed from the school's point of view in the form of students who often skip classes in street vendors and lazy c) for monitoring, sometimes the teacher concerned does not come to the street vendors as scheduled, d) there are assignments in the street vendors that are not understood by students, because there are some materials that are not relevant to what is learned at school.

\section{c) Output Aspects}

Related to the aspects of qualitative data output obtained from interviews with the head of the street vendors program, the head of the expertise program, the supervisor of the street vendors program, supervisors and students who participated in street vendors

Based on interviews that have been carried out, it can be concluded that: a) the evaluation of street vendors is absolutely carried out by officials from the industry, b) the purpose of street vendors and the results of street vendors as a whole are quite balanced, c) the need for new breakthroughs from the school, so that the relevance between school and industry is more leverage. 


\section{d) Outcome Aspects}

Related to the aspects of Outcome qualitative data obtained from interviews with the head of the street vendors program, the head of the expertise program, the supervisor of the street vendors program and the street vendors participating students. Based on the interviews conducted, it can be concluded that: a) To increase the competence of and students before and after implementing street vendors have been achieved well, but it is expected that these changes can be further improved in the future. b) the change in attitude of students after implementing street vendors is also expected to be better

\section{Conclussion}

Based on the research results of the evaluation of industrial work practices (PKL) students of Electrical Engineering students at SMKN 1 Padang, the following conclusions are obtained:

The design (Input) that exists in the Electrical Engineering expertise program at State Vocational High School 1 in terms of the objectives of the PK program, the readiness of students, supervisors, DUDI structures, facilities and infrastructure, program relevance to student needs there are enough categories and need improvement.

The process (process) contained in the Electrical Engineering expertise program at SMK Negeri 1 Padang in terms of the implementation of street vendors, monitoring of street vendors and the implementation of street vendors is in the sufficient category and needs improvement.

The results (Output) that have been achieved by the Electrical Engineering expertise program at SMK Negeri 1 Parang are viewed from the learning assessment of PKL participants being in the sufficient category and need improvement.

The impact (Outcome) that has been achieved by the Electrical Engineering expertise program of SMK Negeri 1 Padang in terms of aspects of increasing students 'competence and changes in students' attitudes after conducting street vendors is in the sufficient category and needs improvement.

\section{Reference}

Ambiyar \& Muhardika, 2019. Program Evaluation Research Methodology. Bandung: Alfabeta

Creswell, John W. 2014. Qualitative, Quantitative, and Mixed Method Approaches Research Design. United States of America: Sage Publications. Inc.

Ministry of Education. 2008 Prakerin Implementation. Jakarta: Director of Vocational High School Development. Director General of Elementary and Middle Education Management.

Iskandar, 2009. Quantitative Research Methodology. Jakarta: Gaung Persada Press.

Powell, T., \& Heneret, E. 2008. Enhancing program performance with logic models

Sukirno Sadono, 2012. Introduction to Micro Economic Theory, Second Edition, Jakarta: PT. Grafindo Persada

Sukardi. 2012. Educational Evaluation: Principles \& Operations. Jakarta: Earth Literacy.

Law No.20 of 2003 concerning the National Education System.

Wakhinuddin, 2009. Program Evaluation. Pa dang: UNP Press. 